\title{
The Need for Emotional Intelligence Training Education in Critical and Stressful Situations: The Case of Covid-19
}

\author{
https://doi.org/10.3991/ijes.v8i3.17235 \\ Athanasios Drigas ${ }^{(凶)}$, Papoutsi Chara \\ N.C.S.R. 'Demokritos', Athens, Greece \\ dr@it.demokritos.gr
}

\begin{abstract}
Critical and stressful situations can emerge in many different forms in our daily life. Sometimes the stressful situations can be more serious in national or global level, such as natural disasters and diseases. In such a difficult and demanding situation, we were with the onset of the virus. At a time when the international medical scientific community is trying to deal with the new threat called Coronavirus, emotional intelligence is contributing decidedly to address this pandemic. Awareness, management, empathy, basic components of emotional intelligence, are especially important for people to control difficult situations as the one we are going through. The need for the development and cultivation of emotional intelligence from the very beginning, starting from the field of education, is strongly apparent so that the child and later the adult can cope with stressful situations. Studies have shown that people with high emotional intelligence can better manage and mitigate stress and adopt strategies of resilience and control.
\end{abstract}

Keywords - Emotional intelligence, stressful situations, awareness, management, empathy, education training, communication, coronavirus, COVID-19.

\section{Introduction}

The reorganization of existing behavioral strategies is triggered by critical situations of lesser or greater intensity and of different forms [1]. Crisis represents a situation which disrupts daily normal reality and danger, uncertainty, instability, and forced action exists [2].

Stress, on the other hand, is defined as a condition in which the body's ability to maintain a stable internal environment is threatened (or considered endangered) and the causes can be external or internal factors. [3]. Stressful conditions can cause intense stress with short-term or/and long-term harmful effects on humans.

According to Goleman, emotional intelligence (EI) and its competencies are a prerequisite for the preservation of mental health in stressful situations and lack of emotional intelligence in such an unstable environment may be the cause of a failed outcome with questionable future consequences [4]. Daniel Goleman (1998) defines Emotional Intelligence/Quotient as the ability to recognize our own feelings and those of others, to motivate, and to handle our emotions to have the best for ourselves and for 
our relationships [4]. According to the Ability EI model, it is the perception, assessment, and management of emotions in yourself and others [5].

However, it was only in a crisis, a pandemic disease-Covid-19-, that it became clear how much emotional intelligence is needed. The coronavirus-disease (COVID-19) is a highly infectious respiratory disease. The World Health Organization declared the coronavirus to be a pandemic [6]. This pandemic was for most of the world's population an unprecedented situation which was very reasonable to bring stress, anxiety, and uncertainty to citizens.

Having a high EQ (Emotional Quotient) does not mean that a person won't feel stress or anxiety about issues in life, let alone a more stressful event, but this person will be aware of his/her situation and the emotions he/she experiences in order to have selfcontrol, self-management and not be seduced by his/her anxiety with very negative physical and psychological consequences. At the same time, a person with high emotional intelligence will be helpful for people who have been overwhelmed by stress and other negative emotions since social awareness, social skills and empathy, superior characteristics of an emotionally intelligent person, will work in a supportive way towards others. High EI is thought to promote the adaptive regulation of distressing emotions [7] and affect the successful management of daily stresses and challenges [8]. People in the face of a crisis tend to stand together and cooperate [9]. They understand that the risk is shared and are worried not only about themselves but also for others [10].

In such a critical situation that humanity is experiencing today, the need for emotional intelligence is imperative. Dr. Abdel-Fattah (2020) is putting the light on the role of emotional intelligence and emotional stability on confronting crises such as the existing crisis of COVID-19 which has global impact and is pointing out the need for the development of emotional intelligence skills [11].

The article provides some insights through literature review on the determining factor of emotional intelligence and its competencies to mitigate stress in everyday life and highlights the need for awareness, self-control, empathy to confront with crises like Covid-19. Furthermore, the importance of integrating emotional intelligence in the curricula of all educational levels and later in the workplace is indicated.

\section{$2 \quad$ Research Findings}

\subsection{Emotional intelligence and stress}

Stress is defined as the reaction to a threat and has both cognitive and emotional aspects [12]. Although stress response is sometimes a healthy and adaptive function in situations of acute challenge [13], in times of high and prolonged stress, negative emotions like fear and anxiety disrupts working memory [14], decrease our intellectual potential, and may cause permanent dysregulation of the neurobiological stress systems [15]. Additionally, stress adversely affects interpersonal, social, and working relationships. 
Clarity of mind, psychological equilibrium and watchfulness can be reduced, and negative inner thoughts can flood a person's mind which emotional intelligence can help control, repair, and calm [16]. Those who do not recognize and understand their emotions have many difficulties in labelling and controlling them. This in turn brings about difficulties in the proper handling and management of stress resulting in deterioration of mental and physical condition of the person. People who have higher levels of emotional intelligence are less likely to succumb to the adverse effects of stress indicating that the ability to regulate the perceived stress directly influences psychological and physical health, fulfilment and can lead to higher levels of pleasure [17]. Evidence suggest that EI may work as "a stress buffer" and people with higher levels of EI tend to be more flexible and recover faster from acute stress [18,19].

Plenty of empirical studies have investigated the associations between EI and stress in many fields. Kevereski et al. (2016) showed that people with high EI tend to be more capable of protecting themselves from stressful situations showing less aggression, more self-discipline and more self-esteem and they do not have the tendency to impair their mental health something that was noticed in low emotionally intelligent persons [20]. People who are skilled in recognizing and regulating their own and other emotions may be better able to cope with stressful and intense conditions [21]. Mikolajczak et al. (2008), showed that high EI (assessed with the TEIQue) was associated with more adaptive ways of managing not only stress, but also a plethora of emotions, positive and negative ones [22].

$\mathrm{Xu}$ et al. (2019), introduced a new method of evacuation simulation by modeling the formation and transmission of emotional panic [23]. They presented an emotional speed model (ERVO), which compounds the effect of emotional panic and local avoidance together for the first time. The results of their experiment show that the overall approach is strong, and in multi-hazard environments can generate more realistic crowds and the dynamics of panic emotions in a crowd. In this direction, similar studies have been done to illustrate the critical role the emotional condition plays in decision-making processes in crowd movement [24,25].

An important and respectable place where increased stress is observed is that of education. Anxiety exists in both teachers-professors and students-university students. Mérida-López \& Extremera (2017) through an extensive literature review showed the negative associations between emotional intelligence and teachers' burnout and highlighted the importance of emotional intelligence in coping with a variety of working stressors [26]. Zysberg et al. (2016) investigated the correlation between emotional intelligence, personality, stress, and burnout among educators showing the potential role of EI in learning settings [27].

Similar research shows the mediating role of emotional intelligence in reducing stress levels in students [28,29]. Emotional intelligence will help students to manage stress in educational processes, in interpersonal/intrapersonal relationships, improve self-awareness and will contribute to their physical and mental well-being. Houghton et al. (2012) developed a model showing that emotion regulation strategies facilitate stress coping among students [30]. 
An area where increased stress and pressure is also observed is that of the medical field. Research on medical students has shown that emotional intelligence is an important factor in managing stress and in better adjustment [31,32]. Medical students with higher levels of emotional intelligence seemed to experience stress levels, but they have the ability to recover faster when engaged in demanding situations in their work area and they are more capable of dealing with them [33]. In several studies, it is also being underlined the importance of integrating Emotional Intelligence in the curricula of medical education for its development by students [34,35]. Furthermore, emotional intelligence allows nurses to develop therapeutically relationships to meet patients' needs, to interact empathetically with patients and patients' families and to better manage stress either their own or that of others such us patients, nursing staff etc. [36].

Another study shows that emotional intelligence mitigates stress and fosters trust is that of Rezvani et al (2019) who examined the impact of EI among software developers working on information systems projects whose working conditions are challenging and rigorous and the levels of stress are increased [37]. Furthermore, the dominant role of emotions in leadership and in working climate is evident [38]. Emotional intelligence can play a vital role in negotiations and mediations where stress may occur. The effective negotiator or mediator besides economic, political, and physical aspects of the process must be aware and manage his or her own emotions but also those of others that are taking part in the procedure [39].

Berrocal et al. (2006) examined the correlation between EI, anxiety and depression among adolescents [40]. Their study revealed that emotional skills are a significant factor to better psychological adjustment. In addition, self-reported EI was negative correlated with levels of depression and anxiety. Other studies' results attest that recognition, discrimination and regulation of emotions are a strong indicator of a better sanity, mental balance, and increased self-esteem [41].

Lack of understanding and inability to control emotions can increase the negative impact of dealing with stress which can have a detrimental effect on health, as misbehaviors and misguided strategies for coping with stress can be adopted. The emotionally intelligent individual would have the ability to cope with such stressful events through alternative strategies for regulating negative emotions (transactional) [42]. A few studies have found that inducing more adaptive mindsets could increase positive emotion, reduce negative health symptoms, and boost physiological functioning under acute stress $[43,44]$.

However, being emotionally intelligent without being active will not bring the desired results. You must have self-awareness, try to improve, and motivate yourself, have the will to be better and develop the emotional skills you already have to manage to get to higher levels. Gohm et al. (2005) in their research stated that EI is auxiliary in the reduction of stress but only among individuals who were also high in self-reported EI (TMMS) [45]. People who had high EI potential but were unaware of their level of emotional intelligence experienced more stress [45].

People who are self-aware, know their abilities, their weaknesses, their emotions and have self-control, may recover more quickly from a situation that has caused them discomfort and probably will focus from the beginning on the problem, on the causes that 
have created it and they will prioritize and select ideal alternatives for its solution (problem solving) [46].

\subsection{Emotional intelligence and its contribution to a pandemic: COVID-19}

The virus brought about many changes in our daily lives. Handwashing, no face touching, gloves and masks, self - isolation, social distancing measures, shut down of public life may have negative effects on both mental and physical health of people [47]. Many of these negative effects can last much longer than the existence of the virus. Concurrent anxiety about the virus and its spread will increase stress levels and any other physical or mental disorders. The abrupt and complete change of daily life comes to trigger the whole difficult and strange situation.

Individuals worry about their lives and the lives of their family, friends, and relatives. The poor, the weak and the ill are especially vulnerable and affected. Another social group which needs a lot of attention and empathy is the older people [48]. When Covid19 was on the rise everything was done from home such us school, work, shopping, play etc. The closure of shops, businesses - small and large - wage cuts, mass layoffs, economic crisis, uncertainty about the future create a domino of negative reactions. Another worrying issue is the matter of xenophobia, discrimination and social stigma toward people, places or things which may have long term consequences $[49,50]$. Schools' closure was another drastic measure to limit the spread of the disease which led to a considerable number of changes [51,52].

One of the central emotional responses during a pandemic is fear [53]. When in peril, people panic-especially when in crowds [54]. Emotional reactions such as fear and anxiety are normal, and they are an indication that our body's natural defense mechanisms have been activated. The problem begins to arise when negative emotions cannot be managed and reach higher levels which may lead to mental distress with irreparable consequences [55]. Integrating mindsets that cultivate emotional intelligence can help people improve stress levels and utilize creatively the negative emotions during a pandemic for positive development and progress. Stress researchers [56] have developed the "3 Cs" model to account for resilience in stressful situations: control, coherence, and connectedness. These are characteristic elements of emotional intelligence at higher levels.

The pandemic of Covid-2019 take us back to similar crisis situations like the SARS outbreak where many psychiatric morbidities had been recorded [57]. Same negative symptoms had been reported during the Ebola virus outbreak and the H1NI1 influenza outbreak $[58,59]$. Health professionals had also reported negative psychological consequences to the medical staff $[60,61]$.

At this point, emotional intelligence comes to the fore and its role is a catalyst for not panicking but for better management from all sides. Negative, unrecognizable, and uncontrolled emotions such as stress, anxiety, and panic can be as contagious as the new disease. Emotions are also recognized as one of the three or four fundamental categories of mental operations. These categories include motivation, emotion, cognition, and consciousness [62]. Positive emotions promote many phenomena documented in cognitive psychology, while a negative feeling inhibits them $[63,64]$ and they also play 
a meaningful role in the process of coping with stressful situations and better management $[65,66]$. Individuals with positive emotions and positive mindsets, demonstrate better coping strategies and are more innovative in their thinking and more resilient $[67,68]$. Loving-kindness meditation (LKM) is a practice where positive emotions are increased, and negative emotions are decreased. By displaying positive emotions such as compassion, kindness, and empathy, it can then have a contagious effect on others and provide benefits like improving well-being and emotional intelligence [69,70]. We must not only stay in the realm of the "I", but also move on to the "we".

In difficult times we must act on the basis that we are all in this together, for the common good [71], considering the feelings and needs of others, indicative of emotional intelligence. Individuals from many sectors charged to help people - infected or not from the Covid-19 - must be able to put themselves in other shoes and see things from their perspective. Studies have shown that doctors' levels of EI and attachment styles have a positive impact on emotional responses of patients [72]. At the present stage doctors' and nursing staffs' EI is a determining factor. Working with doctors and nurses with higher levels of EI make patients feel better, safer, have greater contentment [73] because they feel that professionals also care for their concerns and their needs, beyond the medical part [72,74]. At the same time, emotional intelligence helps the experts to cope better with their work. It assists them personally, to get to know themselves better, their emotions, to control them, and to better respond to difficult medical situations that create anxiety. Simultaneously, emotional intelligence helps doctors and nurses decode patients' emotions, and thoughts [75] and in this way they better approach and give aid to them to face their illness and their psychological state which plays a decisive role in the outcome of a treatment and a disease. It is important for doctors to communicate on all levels and understand patients' stress or other psychological factors that they are maybe displaying. It is understood that high emotional intelligence can provide doctors with the required knowledge and skill set to be more empathetic, to be more flexible in the methods of approach and facilitate behavioral factors [76,77].

Shanafelt et al. (2020) presented the concerns, the sources of anxiety and the requests of the experts in the health systems, who are in the forefront of help every day, especially in these difficult times [78]. Among the many and important ones is the request from the leaders for support for their emotional needs and point out the significance of genuine gestures of gratitude for their loyalty and their superhuman efforts to care and save their patients putting their own lives in immediate danger [69]. Medical staff must have elements of emotional intelligence to first help themselves and then render assistance to patients either daily or now in this strange and difficult period [79].

Sometimes, like in the current state, we cannot control what has happened, but we can control our reaction to what is happening. Kleinberg et al. (2020) conducted a ground truth dataset on the emotions and the concerns of people in the UK regarding Covid-19 [80]. Participants were asked to indicate their emotions and express them in short or long texts. The quick and huge emotional response (5.000 texts) reveals people's need to express their emotions in public in those difficult times and the need for empathy and somebody to share with.

In times of emergency, it is all too easy to turn inward and focus solely on yourself or your family unit. But research suggests that caring about others is one of the best 
ways to fight feelings of isolation and distancing [81]. Even though we have taken measures to protect ourselves against the spread of the virus, we do not need to be emotionally distant. Providing empathy and kindness is an important factor in better coping with a difficult situation and quickly recovering in the aftermath of the crisis. Empathy is a supporting and important element for those who express it and for those who receive it. Practicing empathy during the COVID-19 pandemic not only broadens your spiritual horizons for what others are feeling, thinking, and experiencing, but it can also lead to social connectedness that can help people with combat and stressful feelings [82].

A study conducted to identify the best practices and lessons learned during the 2009 H1N1 pandemic public information and crisis communication campaign emphasizes that an effective communication from all the stakeholders should contain the authentic expression of empathy [83]. Communication laced with emotional intelligence is the bond that binds stakeholders and the public by empowering both, especially the latter. Otherwise, nervousness, anxiety, ambiguity, and insecurity will prevail with conflicting and controversial results [84].

In situations of crisis and panic, a decisive, encouraging, and motivating role belongs to the leadership, whether it is leadership at work or leadership of a country. When people panic, leaders need to cultivate a sense that "we are all in this together" [85]. Empathy is important to understand what kind of emotions are at play and what communicational approaches to use to improve people's emotional responses in an emergency [86]. An emotionally intelligent leader will handle any crisis, big or small, probably better than someone without EI competencies. Self-awareness, self-management, social-awareness, and relationship management - can help a leader cope with any kind of crisis with lower levels of stress, less emotional reactivity, and fewer unintended consequences. Messages and speeches from leaders, specialists and authorities should not be limited to provide only information but should be designed to elicit positive emotions too other than negative ones [87]. To instill a positive mindset and reduce stress as well as change behavior, both emotional and empathetic elements need to be present $[88,89]$. To deal with a crisis, it would be advantageous to have an open and empathetic communication approach [90] that would result in trust and positive action [91]. Unity and cohesion are important, so people feel supported and not alone in such a difficult time. They need someone to understand them to remain optimistic, resilient, and adaptive. In a study, Veil et al. (2011) provided examples and guidelines on how social media can be used to help professionals follow best practices in risk and crisis communication [92]. Among the instructions and the guidelines, they pointed out the significance of communication with compassion, concern and empathy and they added that recognizing and understanding emotions allows for an open exchange that humanizes the reaction to a crisis. Moreover, they highlighted the fact that social media should listen to the public's concerns. Their truly emotional words, authentic speech and empathetic support will help people feel confidence, be strong and have hope [93].

On the other hand, social networks can also foster a sense of connection [54]. Today, technology is an integral part of our lives. Even more at this difficult time, people are connecting to social media to be informed about the disease, but they are also connecting to social groups to interact, to talk about how they are experiencing the situation, to 
express their emotions and to gain strength and courage from others. Additionally, information-rich, dyadic, and temporarily synchronous technologies tend to be best suited to producing empathy and connection [94]. Digital social and psychological support for vulnerable people bolster their psychological well-being and social regulation [95].

WHO (2020) urges people to be empathetic to all, infected or not, to support emotionally people in need and to be helpful with various ways [96]. Moreover, WHO points out that it is reasonable to feel pressure and stress in the current situation, but it encourages us to pay attention to our needs and emotions and to try to manage and ameliorate our mental health and our psychosocial well-being. Children must be also motivated to express their emotions thus emphasizing the important role of emotions (expression and recognition) at all ages and in all social situations even more on those that evoke negative ones.

\section{Discussion and Conclusion}

Stress is a situation with uncontrollable and negative results in which a person may show inability to cope and therefore causes constant changes in the mind, in the emotions and in the mental processes of the person. [97]. Stress, as an intense emotional state, has characteristics that should make it stand out when a person is overwhelmed by it and it would be more constructive to be properly managed by people who are under pressure and those around them. [98].

Individuals who understand the nature and the causes of their feelings, and who are proficient in emotion-regulation abilities, are generally less likely to collapse under the pressure of experimental or real-life stressors; they are also more likely to take precautionary measures for the restoration of their emotional balance and the resolution of their problems. In addition, the conscious use of EI resources, whether assisted or inherent, helps maximize the effectiveness of the overall response effort. Adaptive coping, in turn, helps reduce the intensity and duration of stressful experiences and thus, minimizes the creation of health problems associated with chronic hyper-activation of physiological stress-response systems. An emotionally intelligent person, when under pressure and in difficult circumstances, may have superior skills that allow him or her to manage a stressful situation directly and effectively or to take advantage of this situation as a source and motivation for learning and intellectual and spiritual growth [99]. Emotional intelligence empowers people to be effective at reducing fear and worry as well as enhancing resilience and recovery during the CoVid-19 pandemic and the years that will follow.

Empathy is always important, but it is particularly vital during a public health crisis [100]. Empathic listening helps people express emotions, reveal inner thoughts, be strong, decrease stress because someone else listens and gives full attention to their needs and concerns. In these ways it is possible to find meaning and cope effectively with fear and the challenges presented by the pandemic or any other challenges that may occur $[69,101]$. Empathy can act as a mediator in the healthy maintenance of mental and physical health as individuals through the whole process are evolved cognitively and emotionally [102]. In their study Pfattheicher et al. 2020 show that (i) empathy is 
indeed a basic motivation for physical distancing, and (ii) activating empathy for those most vulnerable to the virus mobilize them to adjust to physical distancing [103].

According to Goleman, the "minds" of an individual, the rational and the emotional, are both together responsible for shaping the individual as a personality, for shaping his future and for dealing with everyday challenging scenarios [104]. Research has also shown positive association between emotional intelligence and mental processes $[105,106]$. Emotional intelligence (E.I.) implies the ability to reason accurately about emotions. It is the effective use of emotions and emotional knowledge to further enhance the thought process [8]. When a decision must be made people use their rational thinking considering the positive and negative attributes of a situation. But people cannot be separated from their emotions. In handling a critical and stressful event our emotions are present for the proper action and decision [107,108]. An emotionally intelligent individual will recognize stress or other negative feelings, will not panic, will handle these emotions because he/she has self-control and self-management and as a consequence he/she will detect stress and anxiety to other individuals and due to social management will provide the necessary help because the final target is common- to be optimistic, to be resilient, and to overcome a difficult situation whether it is called a virus or something else.

The planet sounds the alarm bell. Cognitive intelligence must work together harmoniously with emotional intelligence for the common good. People need to acquire selfsocial awareness and self-social management for the universality of emotions to exist and to remedy stressful situations and global problems. Each of us is part of a community and at the same time we are part of a global community. We belong to a more general social whole. That is why we tend to take care of each other and seek the social and emotional support of others. On the global epidemic, we realized that the world community is interconnected and that various pathogens are not limited to borders between countries and states [109].

Because of EI's significance there should be a thought about including courses and programs for cultivating, developing, and enhancing emotional intelligence at all levels of education [110-112]. The training of emotional skills, besides cognitive and social ones, is necessary. The pandemic has brought to the surface structural changes that need to be made, starting mainly in the field of education [113].

In the article, an attempt was made to show the positive role of emotional intelligence in reducing or eliminating stress in various areas. Then we focused on the important role of emotional intelligence in an intense stressful situation like the one with the pandemic.

"According to Darwin's Origin of Species, it is not the most intellectual of the species that survives; it is not the strongest that survives; but the species that survives is the one that is able best to adapt and adjust to the changing environment in which it finds itself." [114]

Megginson, 1963. 


\section{$4 \quad$ References}

[1] Mamzer, H. (2020). Postmodern Society And COVID-19 Pandemic: Old, New And Scary. Society Register, 4(2), 7-18. https://doi.org/10.14746/sr.2020.4.2.01

[2] Samman, A. (2015). Crisis theory and the historical imagination. Review of International Political Economy, 22(5), 966-995. https://doi.org/10.1080/09692290.2015.1011682

[3] Chrousos, G. P. (2009). Stress and disorders of the stress system. Nature reviews endocrinology, 5(7), 374 .

[4] Goleman, D. (1998). Working with emotional intelligence. London: Bloomsbury Publishing plc.

[5] Mayer, J.D.; Roberts, R.D.; Barsade, S.G. Human abilities: Emotional intelligence. Annu. Rev. Psychol. 2008, 59, 507-536. https://doi.org/10.1146/annurev.psych.59.103006.0936 $\underline{46}$

[6] Fuchs, C. (2020). Everyday Life and Everyday Communication in Coronavirus Capitalism. tripleC: Communication, Capitalism \& Critique. Open Access Journal for a Global Sustainable Information Society, 18(1), 375-399. https://doi.org/10.31269/triplec.v18i1.1167

[7] Salovey, P. (2001). Applied emotional intelligence: Regulating emotions to become healthy, wealthy, and wise. Emotional intelligence and everyday life, 168-184.

[8] Bar-On, R., Jam-on, R., \& Bar-Shavit, R. (1997). The emotional quotient inventory (EQ-i): Technical manual.

[9] Drury, J. (2018). The role of social identity processes in mass emergency behaviour: An integrative review. European Review of Social Psychology, 29(1), 38-81. https://doi.org/ $\underline{10.1080 / 10463283.2018 .1471948}$

[10] Drury, J., Cocking, C., \& Reicher, S. (2009). The nature of collective resilience: Survivor reactions to the 2005 London bombings. International Journal of Mass Emergencies and Disasters, 27(1), 66-95.

[11] Dr. Abdel-Fattah HMM. Emotional Intelligence and Emotional Stability in Crises. Journal of Psychiatry and Psychiatric Disorders 4 (2020): 56-62. https://doi.org/10.26502/jppd. 2572-519x0090

[12] Lazarus, R. S. (1966). Psychological stress and the coping process.

[13] Engert, V., Linz, R., \& Grant, J. A. (2019). Embodied stress: The physiological resonance of psychosocial stress. Psychoneuroendocrinology, 105, 138-146. https://doi.org/10.1016/ j.psyneuen.2018.12.221

[14] Khayyer, Z., Nejati, V., \& Fathabadi, J. (2017). Stress Induction and Visual Working Memory Performance: The Effects of Emotional and Non-Emotional Stimuli. Biotechnology and Health Sciences, 4(2), e57652. https://doi.org/10.5812/bhs.57652

[15] McEwen, B. S., Bowles, N. P., Gray, J. D., Hill, M. N., Hunter, R. G., Karatsoreos, I. N., \& Nasca, C. (2015). Mechanisms of stress in the brain. Nature neuroscience, 18(10), 1353. https://doi.org/10.1038/nn.4086

[16] Salovey, P., Mayer, J. D., Goldman, S. L., Turvey, C., \& Palfai, T. P. (1995). Emotional attention, clarity, and repair: Exploring emotional intelligence using the Trait Meta-Mood Scale. https://doi.org/10.1037/10182-006

[17] Ruiz-Aranda, D., Extremera, N., \& Pineda-Galan, C. (2014). Emotional intelligence, life satisfaction and subjective happiness in female student health professionals: the mediating effect of perceived stress. Journal of psychiatric and mental health nursing, 21(2), 106-113. https://doi.org/10.1111/jpm.12052

[18] Lea, R. G., Davis, S. K., Mahoney, B., \& Qualter, P. (2019). Does emotional intelligence buffer the effects of acute stress? A systematic review. Frontiers in psychology, 10. https:// doi.org/10.3389/fpsyg.2019.00810 
[19] Pool, L. D., \& Qualter, P. (Eds.). (2018). An introduction to emotional intelligence. John Wiley \& Sons.

[20] Kevereski, L., Dimovska, M. K., \& Ristevski, D. (2016). The influence of the emotional intelligence in protection of the mental health in conditions of a psychosocial stress. International Journal of Cognitive Research in Science, Engineering and Education, 4(1), 17. https://doi.org/10.5937/ijcrsee1601017k

[21] Hammen, C. (2005). Stress and depression. Annu. Rev. Clin. Psychol., 1, 293-319.

[22] Mikolajczak, M., Nelis, D., Hansenne, M., \& Quoidbach, J. (2008). If you can regulate sadness, you can probably regulate shame: Associations between trait emotional intelligence, emotion regulation and coping efficiency across discrete emotions. Personality and individual differences, 44(6), 1356-1368. https://doi.org/10.1016/j.paid.2007.12.004

[23] Xu, M., Xie, X., Lv, P., Niu, J., Wang, H., Li, C., \& Zhou, B. (2019). Crowd behavior simulation with emotional contagion in unexpected multihazard situations. IEEE Transactions on Systems, Man, and Cybernetics: Systems. https://doi.org/10.1109/tsmc.2019.2899 $\underline{047}$

[24] Fu, L., Song, W., Lv, W., \& Lo, S. (2014). Simulation of emotional contagion using modified sir model: A cellular automaton approach. Physica A: Statistical Mechanics and its Applications, 405, 380-391. https://doi.org/10.1016/j.physa.2014.03.043

[25] Tsai, J., Fridman, N., Bowring, E., Brown, M., Epstein, S., Kaminka, G., \& Taylor, M. E. (2011, May). Escapes: evacuation simulation with children, authorities, parents, emotions, and social comparison. In The 10th International Conference on Autonomous Agents and Multiagent Systems-Volume 2 (pp. 457-464). International Foundation for Autonomous Agents and Multiagent Systems. https://doi.org/10.1145/1329125.1329336

[26] Mérida-López, S., \& Extremera, N. (2017). Emotional intelligence and teacher burnout: A systematic review. International Journal of Educational Research, 85, 121-130. https:// doi.org/10.1016/j.ijer.2017.07.006

[27] Zysberg, L., Orenshtein, C., Gimmon, E., \& Robinson, R. (2017). Emotional intelligence, personality, stress, and burnout among educators. International Journal of Stress Management, 24(S1), 122. https://doi.org/10.1037/str0000028

[28] Machera, R. P., \& Machera, P. C. (2017). Emotional Intelligence (EI): A Therapy for Higher Education Students. Universal Journal of Educational Research, 5(3), 461-471. https://doi.org/10.13189/ujer.2017.050318

[29] Bryant, S., \& Malone, T. I. (2015). An empirical study of emotional intelligence and stress in college students. Business Education \& Accreditation, 7(1), 1-11.

[30] Houghton, J. D., Wu, J., Godwin, J. L., Neck, C. P., \& Manz, C. C. (2012). Effective stress management: A model of emotional intelligence, self-leadership, and student stress coping. Journal of Management Education, 36(2), 220-238. https://doi.org/10.1177/1052562911 $\underline{430205}$

[31] Malik, D., Chaudhary, S., \& Kumari, N. (2017). Emotional intelligence and its association with stress level: a study among medical students. International Journal for Innovative Research in Multidisciplinary Field, 3(4), 176-180.

[32] Moghal F, Yasien S, Alvi T, Washdev (2016) Relationship of Emotional Intelligence and Stress in Undergraduate Medical Students. J Psychol Clin Psychiatry 5(3): 00282

[33] Arora, S., Russ, S., Petrides, K. V., Sirimanna, P., Aggarwal, R., Darzi, A., \& Sevdalis, N. (2011). Emotional intelligence and stress in medical students performing surgical tasks. Academic Medicine, 86(10), 1311-1317. https://doi.org/10.1097/acm.0b013e31822bd7aa

[34] Rosenstein, A., \& Stark, D. (2015). Emotional Intelligence: a critical tool to understand and improve behaviors that impact patient care. Journal of Psychology and Clinical Psychiatry, 2(1), 1-4. https://doi.org/10.15406/jpcpy.2015.02.00066 
[35] Cherry, M. G., Fletcher, I., O'sullivan, H., \& Shaw, N. (2012). What impact do structure educational sessions to increase emotional intelligence have on medical students? BEME Guide No. 17. Medical teacher, 34(1), 11-19. https://doi.org/10.3109/0142159x.2011.614 $\underline{293}$

[36] Landa, J. M. A., \& López-Zafra, E. (2010). The impact of emotional intelligence on nursing: An overview. Psychology, 1(1), 50.

[37] Rezvani, A., \& Khosravi, P. (2019). Emotional intelligence: The key to mitigating stress and fostering trust among software developers working on information system projects. International Journal of Information Management, 48, 139-150. https://doi.org/10.1016/ j.ijinfomgt.2019.02.007

[38] Ashkanasy, N. M., \& Dorris, A. D. (2017). Emotions in the workplace. Annual Review of Organizational Psychology and Organizational Behavior, 4, 67-90. https://doi.org/10.1146/ annurev-orgpsych-032516-113231

[39] Kelly, E. J., \& Kaminskiené, N. (2016). Importance of emotional intelligence in negotia tion and mediation. International Comparative Jurisprudence, 2(1), 55-60. https://doi.org/ 10.1016/j.icj.2016.07.001

[40] Fernandez-Berrocal, P., Alcaide, R., Extremera, N., \& Pizarro, D. (2006). The role of emotional intelligence in anxiety and depression among adolescents. Individual Differe nces Research, 4(1).

[41] Fernández-Berrocal, P., Salovey, P., Vera, A., Extremera, N., \& Ramos, N. (2005). Cultu ral influences on the relation between perceived emotional intelligence and depression. International Review of Social Psychology, 18(1), 91-107.

[42] Matthews, G., Zeidner, M., \& Roberts, R. D. (2017). Emotional intelligence, health, and stress. The handbook of stress and health: A guide to research and practice, 312-326. https://doi.org/10.1002/9781118993811.ch18

[43] Crum, A. J., Akinola, M., Martin, A., \& Fath, S. (2017). The role of stress mindset in shaping cognitive, emotional, and physiological responses to challenging and threatening stress. Anxiety, stress, \& coping, 30(4), 379-395. https://doi.org/10.1080/10615806.2016. $\underline{1275585}$

[44] Crum, A. J., Salovey, P., \& Achor, S. (2013). Rethinking stress: The role of mindsets in determining the stress response. Journal of personality and social psychology, 104(4), 716. https://doi.org/10.1037/a0031201

[45] Gohm, C. L., Corser, G. C., \& Dalsky, D. J. (2005). Emotional intelligence under stress: Useful, unnecessary, or irrelevant? Personality and individual differences, 39(6), 1017-1028. https://doi.org/10.1016/j.paid.2005.03.018

[46] Gohm, C. L., \& Clore, G. L. (2002). Four latent traits of emotional experience and their involvement in well-being, coping, and attributional style. Cognition \& Emotion, 16(4), 495518. https://doi.org/10.1080/02699930143000374

[47] Shah, K., Kamrai, D., Mekala, H., Mann, B., Desai, K., \& Patel, R. S. (2020). Focus on mental health during the coronavirus (COVID-19) pandemic: applying learnings from the past outbreaks. Cureus, 12(3), e-7405. https://doi.org/10.7759/cureus.7405

[48] Doraiswamy, S., Cheema, S., \& Mamtani, R. (2020). Older people and epidemics: a call for empathy. Age and Ageing. https://doi.org/10.1093/ageing/afaa060

[49] Schaller, M., \& Neuberg, S. L. (2012). Danger, disease, and the nature of prejudice (s). In Advances in experimental social psychology (Vol. 46, pp. 1-54). Academic Press. https:// doi.org/10.1016/b978-0-12-394281-4.00001-5

[50] Person, B., Sy, F., Holton, K., Govert, B., \& Liang, A. (2004). Fear and stigma: the epidemic within the SARS outbreak. Emerging Infectious Diseases, 10(2), 358. https://doi. org/10.3201/eid1002.030750 
[51] Petretto, D.R.; Masala, I.; Masala, C. Special Educational Needs, Distance Learning, Inclusion and COVID-19. Educ. Sci. 2020, 10, 154. https://doi.org/10.3390/educsci10060154

[52] Golberstein E, Wen H, Miller BF. Coronavirus Disease 2019 (COVID-19) and Mental Health for Children and Adolescents. JAMA Pediatr. Published online April 14, 2020. https://doi.org/10.1001/jamapediatrics.2020.1456

[53] Ahorsu, D. K., Lin, C. Y., Imani, V., Saffari, M., Griffiths, M. D., \& Pakpour, A. H. (2020). The Fear of COVID-19 Scale: Development and Initial Validation. International Journal of Mental Health and Addiction, 1-9. https://doi.org/10.1007/s11469-020-00270-8

[54] Van Bavel, J. J., Boggio, P., Capraro, V., Cichocka, A., Cikara, M., Crockett, M., \& Ellemers, N. (2020). Using social and behavioral science to support COVID-19 pandemic response.

[55] Harper, C. A., Satchell, L., Fido, D., \& Latzman, R. (2020). Functional fear predicts public health compliance in the COVID-19 pandemic. https://doi.org/10.31234/osf.io/jkfu3

[56] Reich, J. W. (2006). Three psychological principles of resilience in natural disasters. Disaster Prevention and Management: An International Journal.

[57] Xiang, Y. T., Yang, Y., Li, W., Zhang, L., Zhang, Q., Cheung, T., \& Ng, C. H. (2020). Timely mental health care for the 2019 novel coronavirus outbreak is urgently needed. The Lancet Psychiatry, 7(3), 228-229. https://doi.org/10.1016/s2215-0366(20)30046-8

[58] Kamara, S., Walder, A., Duncan, J., Kabbedijk, A., Hughes, P., \& Muana, A. (2017). Mental health care during the Ebola virus disease outbreak in Sierra Leone. Bulletin of the World Health Organization, 95(12), 842. https://doi.org/10.2471/blt.16.190470

[59] Taha, S., Matheson, K., Cronin, T., \& Anisman, H. (2014). Intolerance of uncertainty, appraisals, coping, and anxiety: The case of the $2009 \mathrm{H} 1 \mathrm{~N} 1$ pandemic. British journal of health psychology, 19(3), 592-605. https://doi.org/10.1111/bjhp.12058

[60] Lee, S. M., Kang, W. S., Cho, A. R., Kim, T., \& Park, J. K. (2018). Psychological impact of the 2015 MERS outbreak on hospital workers and quarantined hemodialysis patients. Comprehensive psychiatry, 87, 123-127. https://doi.org/10.1016/j.comppsych.2018.10.003

[61] Wei, Y. L., Han, B., Liu, W., Liu, G., \& Huang, Y. (2004). Psychosomatic discomfort and related factors among 1,411 first-line SARS staff in Beijing. In Manual of the 7th national experimental medicine symposium of Chinese Society of Integrated Traditional Chinese and Western Medicine (pp. 6-12).

[62] Bain, A. Review of the Senses and the Intellect; Thoemmes Press: London, NY, USA, 1894.

[63] Clore, G. L., \& Huntsinger, J. R. (2007). How emotions inform judgment and regulate thought. Trends in cognitive sciences, 11(9), 393-399. https://doi.org/10.1016/j.tics.2007. $\underline{08.005}$

[64] Fredrickson, B. L. (2001). The role of positive emotions in positive psychology: The broaden-and-build theory of positive emotions. American psychologist, 56(3), 218. https://doi.org/10.1037/0003-066x.56.3.218

[65] Kim, H. K., \& Niederdeppe, J. (2013). The role of emotional response during an H1N1 influenza pandemic on a college campus. Journal of Public Relations Research, 25(1), 30-50. https://doi.org/10.1080/1062726x.2013.739100

[66] Fredrickson, B. L., Tugade, M. M., Waugh, C. E., \& Larkin, G. R. (2003). What good are positive emotions in crisis? A prospective study of resilience and emotions following the terrorist attacks on the United States on September 11th, 2001. Journal of personality and social psychology, 84(2), 365. https://doi.org/10.1037/0022-3514.84.2.365

[67] Crum, A. J., Akinola, M., Martin, A. \& Fath, S. The role of stress mindset in shaping cognitive, emotional, and physiological responses to challenging and threatening stress. Anxiety Stress Coping 30, 379-395 (2017). https://doi.org/10.1080/10615806.2016.1275585 
[68] Tugade, M. M., \& Fredrickson, B. L. (2004). Resilient individuals use positive emotions to bounce back from negative emotional experiences. Journal of personality and social psychology, 86(2), 320. https://doi.org/10.1037/0022-3514.86.2.320

[69] Polizzi, C., Lynn, S. J., \& Perry, A. (2020). STRESS AND COPING IN THE TIME OF COVID-19: Pathways to Resilience and Recovery. Clinical Neuropsychiatry, 17(2).

[70] Galante, J., Galante, I., Bekkers, M. J., \& Gallacher, J. (2014). Effect of kindness-based meditation on health and well-being: A systematic review and meta-analysis. Journal of consulting and clinical psychology, 82 (6), 1101. https://doi.org/10.1037/a0037249

[71] Carter, H., Drury, J., Rubin, G. J., Williams, R., \& Amlôt, R. (2015). Applying crowd psychology to develop recommendations for the management of mass decontamination. Health security, 13(1), 45-53. https://doi.org/10.1089/hs.2014.0061

[72] Cherry, M. G., Fletcher, I., Berridge, D., \& O’Sullivan, H. (2018). Do doctors' attachment styles and emotional intelligence influence patients' emotional expressions in primary care consultations? An exploratory study using multilevel analysis. Patient education and counseling, 101(4), 659-664. https://doi.org/10.1016/j.pec.2017.10.017

[73] Dube, L., Belanger, M. C., \& Trudeau, E. (1996). The role of emotions in health care satisfaction. Marketing Health Services, 16(2), 45.

[74] Adams, K., Cimino, J. E., Arnold, R. M., \& Anderson, W. G. (2012). Why should I talk about emotion? Communication patterns associated with physician discussion of patient expressions of negative emotion in hospital admission encounters. Patient education and counseling, 89(1), 44-50. https://doi.org/10.1016/j.pec.2012.04.005

[75] Freshwater, D., \& Stickley, T. (2004). The heart of the art: emotional intelligence in nurse education. Nursing inquiry, 11(2), 91-98. https://doi.org/10.1111/j.1440-1800.2004.00198. $\underline{\mathrm{x}}$

[76] Weng, H. C., Hung, C. M., Liu, Y. T., Cheng, Y. J., Yen, C. Y., Chang, C. C., \& Huang, C. K. (2011). Associations between emotional intelligence and doctor burnout, job satisfaction and patient satisfaction. Medical education, 45(8), 835-842. https://doi.org/10.11 11/j.1365-2923.2011.03985.x

[77] Weng, H. C., Chen, H. C., Chen, H. J., Lu, K., \& Hung, S. Y. (2008). Doctors' emotional intelligence and the patient-doctor relationship. Medical education, 42(7), 703-711. https:// doi.org/10.1111/j.1365-2923.2008.03039.x

[78] Shanafelt, T., Ripp, J., \& Trockel, M. (2020). Understanding and Addressing Sources of Anxiety Among Health Care Professionals During the COVID-19 Pandemic. JAMA. https://doi.org/10.1001/jama.2020.5893

[79] Reeves, A. (2005). Emotional intelligence: recognizing and regulating emotions. Aaohn Journal, 53(4), 172-176. https://doi.org/10.1177/216507990505300407

[80] Kleinberg, B., van der Vegt, I., \& Mozes, M. (2020). Measuring Emotions in the COVID19 Real World Worry Dataset. arXiv preprint arXiv:2004.04225.

[81] Inagaki TK, Orehek E. On the benefits of giving social support: when, why, and how support providers gain by caring for others. Current Directions in Psychological Science. 2017;26(2):109-113. https://doi.org/10.1177/0963721416686212

[82] Ratka A. Empathy and the development of affective skills. Am J Pharm Educ. 2018;82 (10):7192. doi:10.5688/ajpe7192

[83] Stoop, A. (2010). The 2009 H1N1 Pandemic Response: Public Information and Crisis Communication in North Carolina.

[84] Brashers, D. E. (2001). Communication and uncertainty management. Journal of communication, 51(3), 477-497. 
[85] Haslam, C., Jetten, J., Cruwys, T., Dingle, G., \& Haslam, S. A. (2018). The new psychology of health: Unlocking the social cure. Routledge. https://doi.org/10.4324/9781315648 $\underline{569-7}$

[86] Sandman, P. Beyond Panic Prevention: Addressing Emotion in Emergency Communication. In Emergency Risk Communication CDCynergy (CD-ROM); Centers for Disease Control and Prevention, US Department of Health and Human Services: Washington, DC, USA, 2003.

[87] Lunn, P. D., Belton, C. A., Lavin, C., McGowan, F. P., Timmons, S., \& Robertson, D. A. (2020). Using Behavioral Science to help fight the Coronavirus. Journal of Behavioral Public Administration, 3(1). https://doi.org/10.30636/jbpa.31.147

[88] Shen, L. (2010). Mitigating psychological reactance: The role of message-induced empathy in persuasion. Human Communication Research, 36(3), 397-422. https://doi.org/10. 1111/j.1468-2958.2010.01381.x

[89] Shen, L. (2015). Targeting smokers with empathy appeal antismoking public service announcements: A field experiment. Journal of health communication, 20(5), 573-580. https://doi.org/10.1080/10810730.2015.1012236

[90] Ruiz de Azua, S., Ozamiz-Etxebarria, N., Ortiz-Jauregui, M. A., \& Gonzalez-Pinto, A. (2020). Communicative and social skills among medical students in Spain: a descriptive analysis. International Journal of Environmental Research and Public Health, 17(4), 1408. https://doi.org/10.3390/ijerph17041408

[91] Xiang, D., Kontos, C., Veloudaki, A., Baka, A., Karnaki, P., \& Linos, A. (2017). Risk Communication in Times of an Epidemic or Pandemic. Asset Paper Series, 5, 1-14.

[92] Veil, S. R., Buehner, T., \& Palenchar, M. J. (2011). A work-in-process literature review: Incorporating social media in risk and crisis communication. Journal of contingencies and crisis management, 19(2), 110-122. https://doi.org/10.1111/j.1468-5973.2011.00639.x

[93] Fransen, K., Haslam, S. A., Steffens, N. K., Vanbeselaere, N., De Cuyper, B., \& Boen, F. (2015). Believing in "us": Exploring leaders' capacity to enhance team confidence and performance by building a sense of shared social identity. Journal of experimental psychology: applied, 21(1), 89. https://doi.org/10.1037/xap0000033

[94] Schroeder, J., Kardas, M., \& Epley, N. (2017). The humanizing voice: Speech reveals, and text conceals, a more thoughtful mind in the midst of disagreement. Psychological science, 28(12), 1745-1762. https://doi.org/10.1177/0956797617713798

[95] Doré, B. P., Morris, R. R., Burr, D. A., Picard, R. W., \& Ochsner, K. N. (2017). Helping others regulate emotion predicts increased regulation of one's own emotions and decreased symptoms of depression. Personality and Social Psychology Bulletin, 43(5), 729-739. https://doi.org/10.1177/0146167217695558

[96] World Health Organization. (2020). Mental health and psychosocial considerations during the COVID-19 outbreak, 18 March 2020 (No. WHO/2019-nCoV/Mental Health/2020.1). World Health Organization.

[97] Mason, J. W. (1968). A review of psychoendocrine research on the pituitary-adrenal cortical system. Psychosomatic medicine, 30(5), 576-607. https://doi.org/10.1097/00006842196809000-00020

[98] White, C. N., \& Buchanan, T. W. (2016). Empathy for the Stressed. Adaptive Human Behavior and Physiology, 2(4), 311-324. https://doi.org/10.1007/s40750-016-0049-5

[99] Zeidner, M., Matthews, G., \& Roberts, R. D. (2012). What we know about emotional intelligence: How it affects learning, work, relationships, and our mental health. MIT press. https://doi.org/10.7551/mitpress/7404.001.0001 
[100] Norris, F. (2001). 50,000 disaster victims speak: An empirical review of the empirical literature, 1981-2001. Atlanta, GA: Georgia State University. https://doi.org/10.1037/e5614 $\underline{62010-001}$

[101] Tennant, K.; Toney-Butler,T.J, Active Listening. In Stat Pearls; Stat Pearls Publishing LLC: Treasure Island, FL, USA,2019.

[102] Campbell, R. G., \& Babrow, A. S. (2004). The role of empathy in responses to persuasive risk communication: Overcoming resistance to HIV prevention messages. Health Communication, 16(2), 159-182. https://doi.org/10.1207/s15327027hc1602_2

[103] Pfattheicher, S., Nockur, L., Böhm, R., Sassenrath, C., \& Petersen, M. B. (2020). The emotional path to action: Empathy promotes physical distancing during the COVID-19 pandemic. https://doi.org/10.31234/osf.io/y2cg5

[104] Daniel Goleman, Emotional Intelligence: Why It Can Matter More Than IQ (New York: Bantam Books, 1995).

[105] Megías, A.; Gutiérrez-Cobo, M.J.; Gómez-Leal, R.; Cabello, R.; Fernández-Berrocal, P. Performance on emotional tasks engaging cognitive control depends on emotional intelligence abilities: An ERP study. Sci. Rep. 2017, 7, 16446. https://doi.org/10.1038/s41598-017$\underline{16657-y}$

[106] Mitchell, R.L.; Phillips, L.H. The overlapping relationship between emotion perception and theory of mind. Neuropsychologia 2015, 70, 1-10. https://doi.org/10.1016/j.neuropsychologia.2015.02.018

[107] Grewal, D., \& Salovey, P. (2005). Feeling Smart: The Science of Emotional Intelligence: A new idea in psychology has matured and shows promise of explaining how attending to emotions can help us in everyday life. American scientist, 93(4), 330-339. https://doi.org/ $\underline{10.1511 / 2005.54 .969}$

[108] Damasio, A. R., \& Sutherland, S. (1994). Descartes' error: Emotion, reason and the human brain. Nature, 372(6503), 287-287.

[109] STANKOVSKA, G., MEMEDI, I., \& DIMITROVSKI, D. (2020). CORONAVIRUS COVID-19 DISEASE, MENTAL HEALTH AND PSYCHOSOCIAL SUPPORT. Society Register, 4(2), 33-48. https://doi.org/10.14746/sr.2020.4.2.03

[110] Rivers, S. E., \& Brackett, M. A. (2020). Transforming education through scientifically rigorous intervention approaches: A call for innovations in the science of emotional intelligence. Trabajo presentado a la National Science Foundation como parte de SBE.'

[111] Mattingly, V., \& Kraiger, K. (2019). Can emotional intelligence be trained? A meta-analytical investigation. Human Resource Management Review, 29(2), 140-155. https://doi. org/10.1016/j.hrmr.2018.03.002

[112] Hodzic, S., Scharfen, J., Ripoll, P., Holling, H., \& Zenasni, F. (2018). How efficient are emotional intelligence trainings: A meta-analysis. Emotion Review, 10(2), 138-148. https://doi.org/10.1177/1754073917708613

[113] Polyakova, Tatiana. (2020). Engineering Pedagogy: on the Way to "Education 4.0". International Journal of Engineering Pedagogy (iJEP). 10. 4. 10.3991/ijep. v10i4.15021. https://doi.org/10.3991/ijep.v10i4.15021

[114] Megginson, L. C. (1963). Lessons from Europe for American business. The Southwestern Social Science Quarterly, 3-13. 


\section{Authors}

Athanasios Drigas is a Research Director at N.C.S.R. 'Demokritos', Institute of Informatics and Telecommunications - Net Media Lab \& Mind-Brain R\&D, Agia Paraskevi, 153 10, Athens, Greece (e-mail: dr@iit.demokritos.gr).

Papoutsi Chara is with Institute of Informatics and Telecommunications - Net Media Lab \& Mind-Brain R\&D, Agia Paraskevi, 153 10, Athens, Greece (e-mail: papoutsi.xara@yahoo.com).

Article submitted 2020-07-23. Resubmitted 2020-08-28. Final acceptance 2020-08-28. Final version published as submitted by the authors. 